\title{
Comparison of Two Powder Processing Techniques on the Properties of $\mathrm{Cu}-\mathrm{NbC}$ Composites
}

\author{
B. D. Long, ${ }^{1}$ R. Othman, ${ }^{2}$ Hussain Zuhailawati, ${ }^{2}$ and M. Umemoto ${ }^{3}$ \\ ${ }^{1}$ Department of Mechanical Engineering, Faculty of Engineering, University of Malaya, 50603 Kuala Lumpur, Malaysia \\ ${ }^{2}$ School of Materials and Mineral Resources Engineering, Engineering Campus, Universiti Sains Malaysia, \\ 14300 Nibong Tebal, Penang, Malaysia \\ ${ }^{3}$ Department of Production Systems, Toyohashi University of Technology, Toyohashi, Aichi 440-0038, Japan
}

Correspondence should be addressed to B. D. Long; longb@um.edu.my

Received 29 May 2013; Revised 31 October 2013; Accepted 31 October 2013; Published 19 January 2014

Academic Editor: Pavel Lejcek

Copyright (C) 2014 B. D. Long et al. This is an open access article distributed under the Creative Commons Attribution License, which permits unrestricted use, distribution, and reproduction in any medium, provided the original work is properly cited.

An in situ $\mathrm{Cu}-\mathrm{NbC}$ composite was successfully synthesized from $\mathrm{Cu}, \mathrm{Nb}$, and $\mathrm{C}$ powders using ball milling and high pressure torsion (HPT) techniques. The novelty of the new approach, HPT, is the combination of high compaction pressure and large shear strain to simultaneously refine, synthesize, and consolidate composite powders at room temperature. The HPTed Cu-NbC composite was formed within a short duration of 20 min without Fe contamination from the HPT's die. High porosity of 3-9\%, Fe and niobium oxidations, from grinding media and ethanol during ball milling led to low electrical conductivity of the milled $\mathrm{Cu}-\mathrm{NbC}$ composite. The electrical conductivity of the HPTed $\mathrm{Cu}-\mathrm{NbC}$ composite showed a value $50 \%$ higher than that of milled $\mathrm{Cu}-\mathrm{NbC}$ composite of the same composition.

\section{Introduction}

Powder metallurgy (P/M) is the most common method for the synthesis of metal matrix composites (MMCs) [1$3]$, whereby the refinement and consolidation are the most important parts of this process. The refinement of powder particles leads to increasing mechanical strength of MMCs as given by the Hall-Petch relationship [4], as well as conferring excellent consolidation/high apparent density which enhances the properties of MMCs [5]. In addition, $\mathrm{P} / \mathrm{M}$ shows many other advantages in the synthesis of MMCs such as homogeneous distribution of reinforcement in the matrix, fine grain size, synthesis process at low temperature, and cost saving. The excellent physical and mechanical properties of MMCs, in particular $\mathrm{Cu}-\mathrm{NbC}$ composites, are applied widely in electrical fields such as electrodes for spot welding, contact materials in high power switches, sliding electrical contacts, and thermal management devices.

In $\mathrm{P} / \mathrm{M}$, ball milling (BM) is well known as a powerful method to synthesize and refine MMCs with extremely fine and homogenous distribution of reinforcement in a metal matrix [6, 7]. However, BM imposes some disadvantages such as contamination from the grinding media and the process control agents (PCAs) during milling [6].

Cold compaction or cold isostatic pressing was used as a conventional consolidation method followed by sintering $[8,9]$. However, these consolidation methods have a major problem which relates to a low density of the bulk material [9, 10]. Therefore, a second process such as hot extrusion, rolling, or forging was usually needed to completely consolidate the final product [11-13]. Previous research work [14] showed that increasing the density of $\mathrm{Cu}-\mathrm{NbC}$ composite from 81 to $96.9 \%$ led to an increase in hardness and electrical conductivity by 3.4 and 5.8 times, respectively. In addition, the consolidation process becomes much more difficult when hard milled powders $[15,16]$ and composite powders containing high volume fraction of reinforcement $[5,17,18]$ are to be consolidated.

Various approaches had been developed to improve the density of the final product by applying high temperature and pressure during sintering, that is, hot pressing or hot pressing followed by rolling $[17,19,20]$. However, powders held at elevated sintering temperatures for long duration 
lead to grain growth and subsequent loss of mechanical properties [21]. Spark plasma sintering (SPS) and shock compaction with very high heating/cooling rates [14, 2224] or extremely high pressure hot pressing (7.7 GPa) [25] have been applied to achieve full density composites without significant grain growth. These consolidation methods are expensive and difficult to apply. In recent years, severe plastic deformation (SPD) methods such as equal channel angular pressing (ECAP) [5, 26], torsion extrusion (TE) [27], and, especially, high pressure torsion (HPT) [28-32] seem to be promising methods for the consolidation of powders.

In this research work, and for the first time, HPT was used to synthesize in situ $\mathrm{Cu}-\mathrm{NbC}$ composite from $\mathrm{Cu}, \mathrm{Nb}$, and $\mathrm{C}$ powders. The role of shear strain in the refinement, synthesis, and consolidation of the composite was investigated. The comparison between HPT and BM was carried out and compared to other methods in order to find the best approach to fabricate MMCs in the future.

\section{Experimental Procedure}

The starting materials used in this research work were copper $(\mathrm{Cu})$, niobium $(\mathrm{Nb})$, and graphite $(\mathrm{C})$ powders with different compositions corresponding to $\mathrm{Cu}-1,5$, and $15 \mathrm{vol} \% \mathrm{NbC}$ in order to study the effects of $\mathrm{NbC}$ volume fraction on the mechanical and electrical properties and the formation of the $\mathrm{Cu}-\mathrm{NbC}$ composite. $\mathrm{Cu}$ powder was of $99.9 \mathrm{wt} \%$ purity with particle size $\leq 180 \mu \mathrm{m}$ (Wako-Japan); Nb powder was of $99.5 \mathrm{wt} \%$ purity with particle size $\leq 7 \mu \mathrm{m}$ (Wako-Japan); and C powder was of $99.9 \mathrm{wt} \%$ purity with particle size $\leq 10 \mu \mathrm{m}$ (Wako-Japan).

The HPT process was conducted at room temperature with equipment as shown in Figure 1. The equipment consists of upper and lower anvils having a shallow circular hole of $20 \mathrm{~mm}$ in diameter and $0.25 \mathrm{~mm}$ depth at the center. A mixture of $\mathrm{Cu}-\mathrm{Nb}-\mathrm{C}$ powders was placed in the hole and compacted at pressures of 1.25 and $5 \mathrm{GPa}$. Subsequently, the lower anvil was rotated relatively to the upper anvil under the imposed pressure of 1.25 or $5 \mathrm{GPa}$ with a rotation speed of $0.5 \mathrm{rpm}$. The $\mathrm{Cu}-15 \mathrm{vol} \% \mathrm{NbC}$ premixed powder was HPTed under a pressure of $1.25 \mathrm{GPa}$ and 10 turns for testing the ability of refinement, formation, and consolidation of the composite powder. The $\mathrm{Cu}-1$ and 5 vol\% $\mathrm{NbC}$ premixed powders were HPTed under a pressure of $5 \mathrm{GPa}$ and 20 turns for investigation of electrical and mechanical properties. No process control agents were used during HPT.

In the $\mathrm{BM}$ method, a mixture of $\mathrm{Cu}-\mathrm{Nb}-\mathrm{C}$ powders was milled using a Fritsch "Pulverisette 5" planetary ball mill under argon atmosphere at a rotation speed of $250 \mathrm{rpm}$ for $30 \mathrm{~h}$. The balls used were $10 \mathrm{~mm}$ in diameter and powderto-ball weight ratio was fixed at $1: 10.1 \mathrm{wt} \%$ of ethanol was used as a process control agent in order to prevent excessive cold welding of these powders during BM. The SUJ-2 balls (chrome steel ball) which have high toughness and wear resistance were chosen in order to reduce contamination during ball collisions. In order to prevent oxidation of the powders, loading and discharging of the powders were carried out inside an argon-filled glove box.

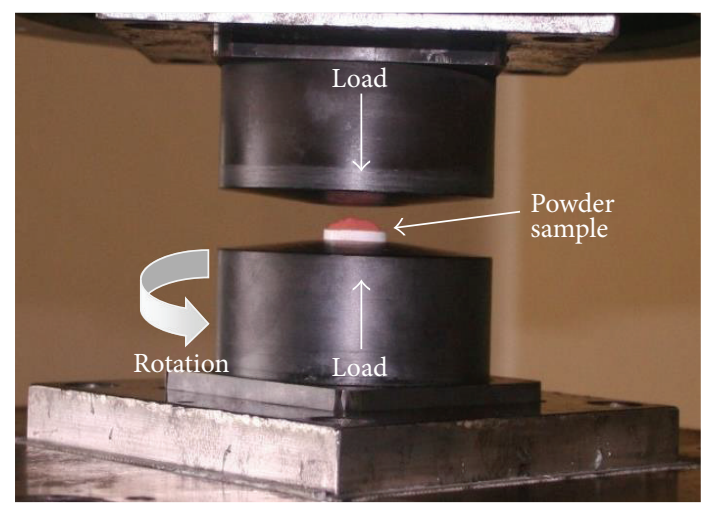

FIGURE 1: Picture of HPT apparatus and processing.

The formation of $\mathrm{NbC}$ in the copper matrix after HPT and BM (labelled as-HPTed and as-milled) was identified using an X-ray diffractometer (XRD; RIGAKU RINT-2500 $\mathrm{X}$-ray diffractometer) with $\mathrm{CuK} \alpha$ radiation. Microstructures of the as-HPTed $\mathrm{Cu}-15 \mathrm{vol} \% \mathrm{NbC}$ sample were investigated using a scanning electron microscope (SEM; LEO Supra $55 \mathrm{VP})$. The as-HPTed $\mathrm{Cu}-1$ and 5 vol\% $\mathrm{NbC}$ samples were annealed at $700^{\circ} \mathrm{C}$ for $1 \mathrm{~h}$ in vacuum. The as-milled $\mathrm{Cu}-$ 1,5 , and $15 \mathrm{vol} \% \mathrm{NbC}$ powders were consolidated by spark plasma sintering (SPS) using a Dr. Sinter @ 2040 spark plasma sintering system (Sumitomo Coal Mining, Tokyo, Japan) at $1000^{\circ} \mathrm{C}, 100 \mathrm{MPa}$ for $10 \mathrm{~min}$. These sintered temperature and pressure were chosen in order to optimize between density, electrical conductivity, and mechanical properties.

The microhardness and electrical conductivity were measured using a Vicker's microhardness tester and Ulvac ZEM 1 electrical conductivity equipment, respectively. Electrical conductivity was measured using the IACS unit whereby IACS refers to the International Annealed Copper Standard and $100 \%$ IACS is equal to $58.0 \mathrm{~m} / \Omega \mathrm{mm}^{2}$. The density of the as-HPTed and SPS $\mathrm{Cu}-\mathrm{NbC}$ milled samples was measured using Archimedes' method. It should be noted that, for HPT samples, tests were conducted at the region $r \geqq 3.5 \mathrm{~mm}$ where a homogeneous microstructure was observed. Three tests were conducted for each measurement. An error of approximately \pm 3 in the microhardness test and an error of $1 \%$ in both the density and electrical measurements were observed.

\section{Results and Discussion}

3.1. The Formation and Refinement of In Situ Cu-NbC Composite Powder. Using SEM micrographs and microhardness measurement along the diameter of the as-HPTed $\mathrm{Cu}$ $15 \mathrm{vol} \% \mathrm{NbC}$ sample, a schematic illustration of microstructure evolution of $\mathrm{Cu}-\mathrm{Nb}-\mathrm{C}$ powders after HPT is given in Figure 2(a). In Figure 2(b), at the center region of the sample where the shear strain was virtually zero and it had undergone nearly pure compression [31], original $\mathrm{Nb}$ particles were unable to refine and high porosity was observed. In the region $r \sim 1.5 \mathrm{~mm}$, most $\mathrm{Nb}$ particles were plastically deformed resulting in the formation of a layered structure. In the region 


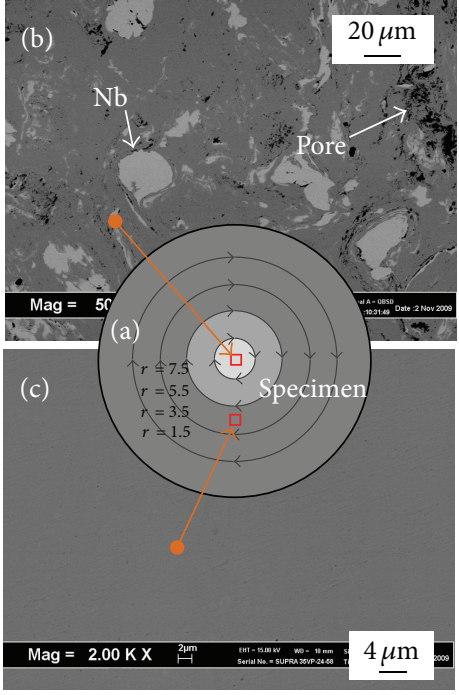

Figure 2: (a) Schematic illustration of microstructural evolution under shear strain and SEM micrographs of the as-HPTed Cu$15 \mathrm{vol} \% \mathrm{NbC}$ at (b) $0 \mathrm{~mm}$ and (c) $3.5 \mathrm{~mm}$ from the center of the sample.

$r \sim 2.5 \mathrm{~mm}$, thin $\mathrm{Nb}$ layers were fractured into small particles and homogeneously distributed in the copper matrix. In the region $r \sim 3.5 \mathrm{~mm}, \mathrm{Nb}$ particles were substantially fractured into very fine particles and homogeneously distributed in the copper matrix. In the region $r \geqq 3.5 \mathrm{~mm}$, where it had undergone large shear strain $(\gamma \geqq 250)$, full density was obtained with extremely fine $\mathrm{Nb}$ distribution in the copper matrix which was undetectable by SEM even at high magnification (Figure 2(c)). This indicates that the large shear strain is an important factor to refine powder particles. The detail of microstructure evolution was described in a previous research [33]. In previous research work [14], it was shown that nanoscale $\mathrm{NbC}$ was formed in situ within the $\mathrm{Cu}$ matrix after ball milling for $30 \mathrm{~h}$.

The in situ formation of NbC in the copper matrix by HPT and $\mathrm{BM}$ was investigated using XRD, as shown in Figure 3. Figure $3(\mathrm{a})$ is the $\mathrm{XRD}$ pattern of a $\mathrm{Cu}-\mathrm{Nb}-\mathrm{C}$ powder mixture. The peaks of $\mathrm{Cu}, \mathrm{Nb}$, and $\mathrm{C}$ can be clearly observed. However, after $\mathrm{BM}$ and $\mathrm{HPT}$, the peaks of $\mathrm{Cu}, \mathrm{Nb}$, and $\mathrm{C}$ become broadened (Figures 3(b) and 3(c)). This is due to high strain and fine particle size. It can also be seen that the XRD patterns of $\mathrm{Cu}-\mathrm{Nb}-\mathrm{C}$ powders after $\mathrm{BM}$ and HPT are quite similar. In $\mathrm{BM}, \mathrm{NbC}$ was formed after $30 \mathrm{~h}$ milling. Similarly, the formation of $\mathrm{NbC}$ was reported to be only after $20 \mathrm{~h}$ of milling [34]. This difference in the duration of $\mathrm{NbC}$ formation by $\mathrm{BM}$ may be attributed to different milling conditions. However, $\mathrm{NbC}$ was formed after only 20 min of HPT deformation (10 turns). This indicates that, similar to BM, the mechanical alloying process also took place during HPT but within a shorter duration. This is probably due to the fact that HPT can impose a certain high level of strain in a shorter duration with sufficient activation energy to accelerate the reaction between $\mathrm{Nb}$ and $\mathrm{C}$. The mechanism of the formation of $\mathrm{NbC}$

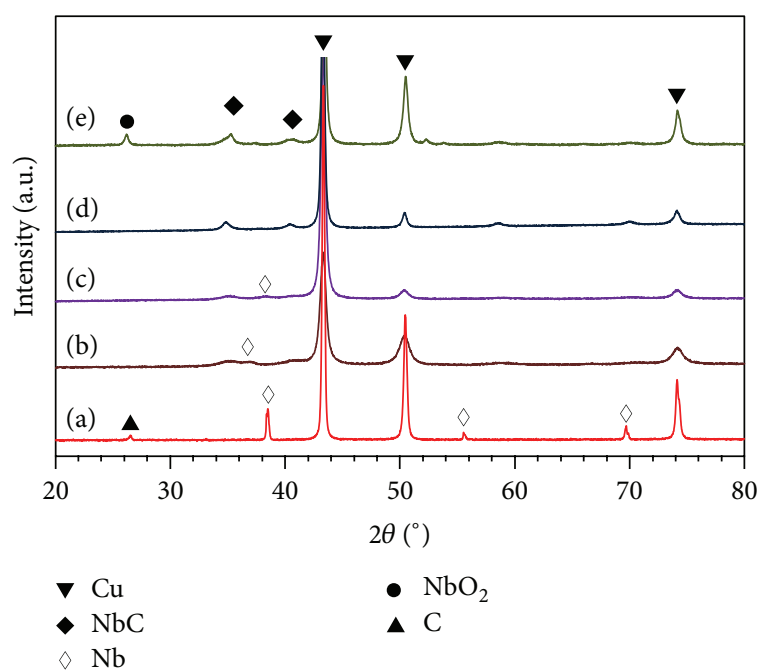

FIGURE 3: XRD patterns of (a) mixture of $\mathrm{Cu}-\mathrm{Nb}-\mathrm{C}$ powder, (b) the as-milled $\mathrm{Cu}-15$ vol $\% \mathrm{NbC}$ powder after $30 \mathrm{~h}$ milling, (c) the asHPTed $\mathrm{Cu}-15$ vol\% NbC compact after 20 min of HPT deformation, (d) the as-HPTed $\mathrm{Cu}-15$ vol\%NbC after annealing, and (e) the asmilled $\mathrm{Cu}-15$ vol\% $\mathrm{NbC}$ compact after SPS.

by mechanical alloying had been discussed in more detail in a previous research work [35].

After annealing, the peaks of $\mathrm{NbC}$ become more evident and no oxidation can be observed in the HPTed sample (Figure 3(d)). However, in the as-milled $\mathrm{Cu}-\mathrm{NbC}$ sample, $\mathrm{NbO}_{2}$ was formed after SPS (Figure 3(e)). This is due to the reaction between $\mathrm{Nb}$ and $\mathrm{O}_{2}$ from the process control agent used. Besides, the EDX analysis results also showed that $\mathrm{Fe}$ was introduced into the composite sample from the grinding media during ball milling [35].

3.2. Consolidation of In Situ $\mathrm{Cu}-\mathrm{NbC}$ Composite Powder. Two processes simultaneously took place during HPT, that is, compaction and torsion. After HPT, the full density of as-HPTed $\mathrm{Cu}-\mathrm{NbC}$ composites was obtained without any need of subsequent sintering process, as shown in Figure 4. The maximum density of the milled $\mathrm{Cu}-\mathrm{NbC}$ composites obtained was only 81 and $98 \%$ of the theoretical density after using normal sintering [14] and SPS (Figure 4), respectively. The density of other composite materials is also presented in Figure 4; that is, the density of $\mathrm{Fe}-\mathrm{TiC}$ [17], $\mathrm{Al}-\mathrm{Al}_{2} \mathrm{O}_{3}$ [5], and $\mathrm{Cu}-\mathrm{Ta}$ [18] composites was reduced with increasing volumes of reinforcement. In these research works, Fe-TiC and $\mathrm{Cu}-\mathrm{Ta}$ composites were fabricated by milling the matrix $(\mathrm{Fe}, \mathrm{Cu})$ and reinforcement $(\mathrm{TiC}, \mathrm{Ta})$ powders together and subsequently compacted and sintered. The $\mathrm{Al}-\mathrm{Al}_{2} \mathrm{O}_{3}$ composite was formed from $\mathrm{Al}$ and $\mathrm{Al}_{2} \mathrm{O}_{3}$ powders using ECAP at $200^{\circ} \mathrm{C}$. The low density of these composites was due to the difficulty in the deformation of hard reinforcement particles in the matrix during consolidation $[8,9]$. It was reported that the yield strength of the composite powder increased with increasing volume fraction of reinforcements $[9,36]$. The increase of yield strength led to a restriction in the 


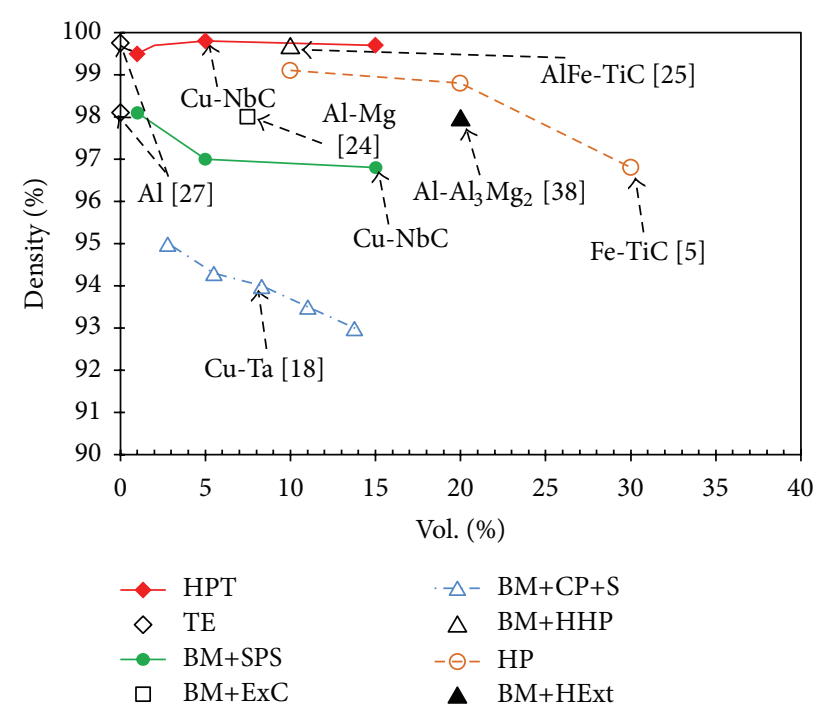

FIgURE 4: Density of different composites and alloys fabricated by different techniques and consolidation methods. HPT: high pressure torsion, $\mathrm{BM}+\mathrm{SPS}$ : ball milling followed by spark plasma sintering, $\mathrm{BM}+\mathrm{CP}+\mathrm{S}$ : ball milling followed by cold compaction and sintering, HP: hot pressing, TE: torsion extrusion, $\mathrm{BM}+\mathrm{ExC}$ : ball milling followed by explosive consolidation, $\mathrm{BM}+\mathrm{HHP}$ : ball milling followed by high pressure hot pressing, and BM+HExt: ball milling followed by hot extrusion.

deformation of particles to fill in the pores and, subsequently, inhibited the densification process [17].

Using HPT, composite powders were severely deformed by large shear strain under high compaction pressure and the pores were easily removed even at high volume fractions of reinforcement. The role of shear strain in cold consolidation can be assessed by the density of $\mathrm{Cu}-15$ vol\% $\mathrm{NbC}$ compact before and after HPT. As a result, the green density of the compact under pressure of $1.25 \mathrm{GPa}$ without torsion was only $91.0 \%$ of the theoretical density. Another research work also reported that compaction of powders was not feasible by mere application of a pressure, even at $6 \mathrm{GPa}$, without rotation to induce strain [31]. This indicates that large shear strain plays a key role to consolidate composite powders to full density. Currently, the role of shear strain in the consolidation of powders was also well recognized by other research works $[5,27,37]$.

With this successful refinement, consolidation, and synthesis of full density MMCs, HPT promises to be a potential low-cost method for the fabrication of MMC powders, alloys, and intermetallics in the future. Besides, HPT had also been reported to enhance the consolidation process of ceramic materials even at low sintering temperatures [31]. Furthermore, HPT shows to be superior in the consolidation of composite powders than equal channel angular extrusion (ECAE) [37], hot extrusion [38], TE [27], and ECAP [5] where heat $\left(400,400,350\right.$, and $200^{\circ} \mathrm{C}$, resp.) was needed during consolidation.

3.3. Properties of In Situ Cu-NbC Composite Fabricated by HPT and BM. Electrical conductivity and microhardness of

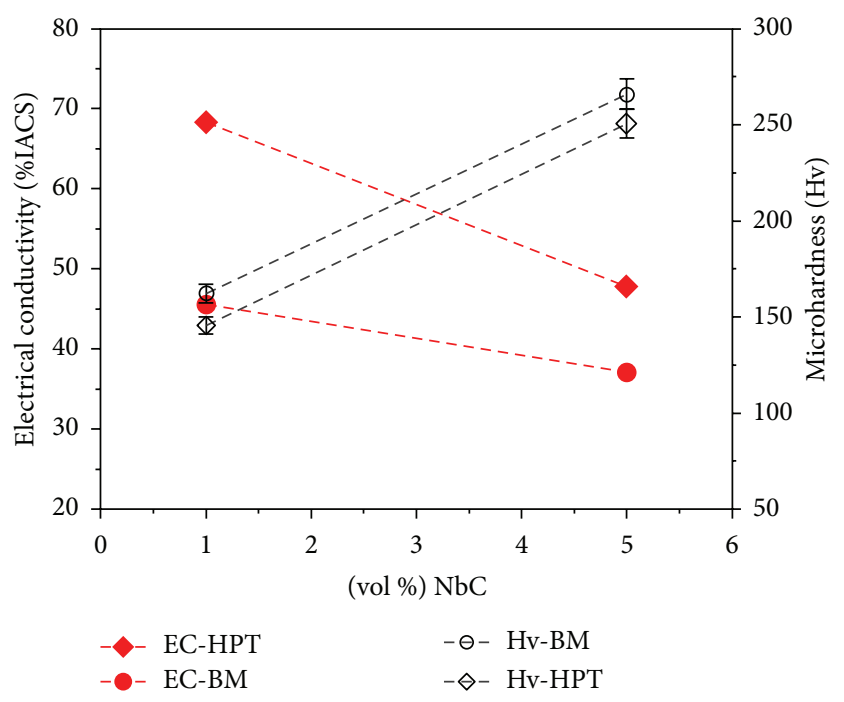

FIgure 5: Comparison of electrical conductivity of $\mathrm{Cu}-\mathrm{NbC}$ composites fabricated by HPT and BM methods; EC-HPT and HvHPT are electrical conductivity and microhardness of HPTed $\mathrm{Cu}-$ $\mathrm{NbC}$ composites, respectively; EC-BM and EC-BM are electrical conductivity and microhardness of milled $\mathrm{Cu}-\mathrm{NbC}$ composites, respectively.

HPTed and milled $\mathrm{Cu}-\mathrm{NbC}$ composites are plotted together in Figure 5. It can be seen that, using HPT as a fabrication method, the electrical conductivity of the $\mathrm{Cu}-\mathrm{NbC}$ composites is significantly increased compared to composites synthesized using BM and sintered by SPS. For instance, at $1 \mathrm{vol} \% \mathrm{NbC}$, the electrical conductivity of the HPTed $\mathrm{Cu}-$ $\mathrm{NbC}$ composites is $50 \%$ higher than that of the milled $\mathrm{Cu}$ $\mathrm{NbC}$ composite, whilst the microhardness of $\mathrm{HPTed} \mathrm{Cu}-\mathrm{NbC}$ composite is only $9 \%$ lower than that of the milled $\mathrm{Cu}-\mathrm{NbC}$ composite. The large improvement of electrical conductivity of the HPTed $\mathrm{Cu}-\mathrm{NbC}$ composites is considered to be attributable to its higher density and virtually nonexistent contamination. The higher microhardness observed in the milled $\mathrm{Cu}-\mathrm{NbC}$ composite is possibly due to the introduction of $\mathrm{Fe}$ and oxides in the copper matrix during milling and sintering [35].

\section{Conclusions}

HPT is a self-cold consolidation process where composite powders can be consolidated to full density at room temperature. The large shear strain of HPT plays the most important role in the refinement, synthesis, and consolidation of fully densified $\mathrm{Cu}-\mathrm{NbC}$ composite. Even though both $\mathrm{BM}$ and HPT can synthesize in situ $\mathrm{Cu}-\mathrm{NbC}$ composite, HPT can perform the process in a much shorter duration (20 min).

The HPTed $\mathrm{Cu}-1$ vol\%NbC composite fabricated using HPT showed high electrical conductivity in combination with high microhardness (68\% IACS and $150 \mathrm{Hv}$ ) and high thermal stability $\left(700^{\circ} \mathrm{C}\right)$. The great improvement of the electrical conductivity of the HPTed $\mathrm{Cu}-\mathrm{NbC}$ composite compared to that of milled $\mathrm{Cu}-\mathrm{NbC}$ composite was due to 
its higher density and nonexistence of contamination. HPT is not only a powerful tool for the synthesis of in situ $\mathrm{Cu}$ based composite powders but also a promising technique for the synthesis of other metal matrix composites.

\section{Conflict of Interests}

The authors declare that there is no conflict of interests regarding the publication of this paper.

\section{Acknowledgments}

This work was supported by The Japan International Cooperation Agency (JICA) under the Asia University Network/Southeast Asia Engineering Education Development Network (AUNSEED/Net). The authors would like to thank Dr. Yoshikazu Todaka for his advice.

\section{References}

[1] K. Yamaguchi, N. Takakura, and S. Imatani, "Compaction and sintering characteristics of composite metal powders," Journal of Materials Processing Technology, vol. 63, no. 1-3, pp. 364-369, 1997.

[2] M. Rahimian, N. Parvin, and N. Ehsani, "Investigation of particle size and amount of alumina on microstructure and mechanical properties of $\mathrm{Al}$ matrix composite made by powder metallurgy," Materials Science and Engineering A, vol. 527, no. 4-5, pp. 1031-1038, 2010.

[3] I. M. Meléndez, E. Neubauer, and H. Danninger, "Consolidation of titanium matrix composites to maximum density by different hot pressing techniques," Materials Science and Engineering A, vol. 527, no. 16-17, pp. 4466-4473, 2010.

[4] R. Z. Valiev, N. A. Enikeev, M. Y. Murashkin, V. U. Kazykhanov, and X. Sauvage, "On the origin of the extremely high strength of ultrafine-grained $\mathrm{Al}$ alloys produced by severe plastic deformation," Scripta Materialia, vol. 63, no. 9, pp. 949-952, 2010.

[5] R. H. Derakhshandeh and A. Jenabali Jahromi, "An investigation on the capability of equal channel angular pressing for consolidation of aluminum and aluminum composite powder," Materials and Design, vol. 32, no. 6, pp. 3377-3388, 2011.

[6] C. Suryanarayana, Mechanical Alloying and Milling, Marcel Dekker, New York, NY, USA, 2004.

[7] H. Ahamed and V. Senthilkumar, "Role of nano-size reinforcement and milling on the synthesis of nano-crystalline aluminium alloy composites by mechanical alloying," Journal of Alloys and Compounds, vol. 505, no. 2, pp. 772-782, 2010.

[8] C. S. Rao and G. S. Upadhyaya, "2014 and 6061 aluminium alloybased powder metallurgy composites containing silicon carbide particles/fibres," Materials and Design, vol. 16, no. 6, pp. 359366, 1995.

[9] I. Sridhar and N. A. Fleck, "Yield behaviour of cold compacted composite powders," Acta Materialia, vol. 48, no. 13, pp. 33413352, 2000.

[10] C. Poletti, M. Balog, T. Schubert, V. Liedtke, and C. Edtmaier, "Production of titanium matrix composites reinforced with $\mathrm{SiC}$ particles," Composites Science and Technology, vol. 68, no. 9, pp. 2171-2177, 2008.

[11] Y. Kawamura, H. Kato, A. Inoue, and T. Masumoto, "Effects of extrusion conditions on mechanical properties in $\mathrm{Zr}-\mathrm{Al}-\mathrm{Ni}-\mathrm{Cu}$ glassy powder compacts," Materials Science and Engineering A, vol. 219, no. 1-2, pp. 39-43, 1996.

[12] L. E. G. Cambronero, E. Sánchez, J. M. Ruiz-Roman, and J. M. Ruiz-Prieto, "Mechanical characterisation of AA7015 aluminium alloy reinforced with ceramics," Journal of Materials Processing Technology, vol. 143-144, no. 1, pp. 378-383, 2003.

[13] J. Oñoro, M. D. Salvador, and L. E. G. Cambronero, "Hightemperature mechanical properties of aluminium alloys reinforced with boron carbide particles," Materials Science and Engineering A, vol. 499, no. 1-2, pp. 421-426, 2009.

[14] B. D. Long, R. Othman, M. Umemoto, and H. Zuhailawati, "Spark plasma sintering of mechanically alloyed in situ copperniobium carbide composite," Journal of Alloys and Compounds, vol. 505, no. 2, pp. 510-515, 2010.

[15] D. L. Zhang, S. Raynova, C. C. Koch, R. O. Scattergood, and K. M. Youssef, "Consolidation of a $\mathrm{Cu}-2.5$ vol.\% Al2O3 powder using high energy mechanical milling," Materials Science and Engineering A, vol. 410-411, pp. 375-380, 2005.

[16] H. Zuhailawati and T. L. Yong, "Consolidation of dispersion strengthened copper-niobium carbide composite prepared by in situ and ex situ methods," Materials Science and Engineering A, vol. 505, no. 1-2, pp. 27-30, 2009.

[17] E. Pagounis, M. Talvitie, and V. K. Lindroos, "Consolidation behavior of a particle reinforced metal matrix composite during hiping," Materials Research Bulletin, vol. 31, no. 10, pp. 12771285, 1996.

[18] T. Venugopal, K. Prasad Rao, and B. S. Murty, "Mechanical and electrical properties of $\mathrm{Cu}$-Ta nanocomposites prepared by high-energy ball milling," Acta Materialia, vol. 55, no. 13, pp. 4439-4445, 2007.

[19] M. López, J. A. Jiménez, and D. Corredor, "Precipitation strengthened high strength-conductivity copper alloys containing ZrC ceramics," Composites A, vol. 38, no. 2, pp. 272-279, 2007.

[20] J. Zhang, L. He, and Y. Zhou, "Highly conductive and strengthened copper matrix composite reinforced by $\mathrm{Zr}_{2} \mathrm{Al}_{3} \mathrm{C}_{4}$ particulates," Scripta Materialia, vol. 60, no. 11, pp. 976-979, 2009.

[21] D. S. Perera, M. Tokita, and S. Moricca, "Comparative Study of Fabrication of $\mathrm{Si}_{3} \mathrm{~N}_{4} / \mathrm{SiC}$ Composites by Spark Plasma Sintering and Hot Isostatic Pressing," Journal of the European Ceramic Society, vol. 18, no. 4, pp. 401-404, 1998.

[22] R. Vintila, A. Charest, R. A. L. Drew, and M. Brochu, "Synthesis and consolidation via spark plasma sintering of nanostructured Al-5356/B4C composite," Materials Science and Engineering A, vol. 528, no. 13-14, pp. 4395-4407, 2011.

[23] K. S. Kumar, P. S. Raj, T. B. Bhat, and K. Hokamoto, "Studies on shock consolidated 2124 Al-40 vol.\% SiCp composites," Journal of Materials Processing Technology, vol. 115, no. 3, pp. 396-401, 2001.

[24] M. Brochu, T. Zimmerly, L. Ajdelsztajn, E. J. Lavernia, and G. Kim, "Dynamic consolidation of nanostructured Al-7.5\% Mg alloy powders," Materials Science and Engineering A, vol. 466, no. 1-2, pp. 84-89, 2007.

[25] M. Krasnowski and T. Kulik, "Nanocrystalline FeAl-TiN composites obtained by hot-pressing consolidation of reactively milled powders," Scripta Materialia, vol. 57, no. 6, pp. 553-556, 2007.

[26] M. Balog, F. Simancik, O. Bajana, and G. Requena, "ECAP vs. direct extrusion-techniques for consolidation of ultra-fine $\mathrm{Al}$ particles," Materials Science and Engineering A, vol. 504, no. 1-2, pp. 1-7, 2009. 
[27] M. Jahedi and M. H. Paydar, "Study on the feasibility of the torsion extrusion (TE) process as a severe plastic deformation method for consolidation of Al powder," Materials Science and Engineering A, vol. 527, no. 20, pp. 5273-5279, 2010.

[28] R. Z. Valiev, R. S. Mishral, J. Grozal, and A. K. Mukherjee, "Processing of nanostructured nickel by severe plastic deformation consolidation of ball-milled powder," Scripta Materialia, vol. 34, no. 9, pp. 1443-1448, 1996.

[29] V. V. Stolyarov, Y. T. Zhu, T. C. Lowe, R. K. Islamgaliev, and R. Z. Valiev, "Processing nanocrystalline Ti and its nanocomposites from micrometer-sized Ti powder using high pressure torsion," Materials Science and Engineering A, vol. 282, no. 1-2, pp. 78-85, 2000.

[30] J. Sort, D. C. Ile, A. P. Zhilyaev et al., "Cold-consolidation of ballmilled Fe-based amorphous ribbons by high pressure torsion," Scripta Materialia, vol. 50, no. 9, pp. 1221-1225, 2004.

[31] K. Edalati and Z. Horita, "Application of high-pressure torsion for consolidation of ceramic powders," Scripta Materialia, vol. 63, no. 2, pp. 174-177, 2010.

[32] P. Jenei, E. Y. Yoon, J. Gubicza, H. S. Kim, J. L. Lábár, and T. Ungár, "Microstructure and hardness of copper-carbon nanotube composites consolidated by High Pressure Torsion," Materials Science and Engineering A, vol. 528, no. 13-14, pp. 4690-4695, 2011.

[33] B. D. Long, M. Umemoto, Y. Todaka, R. Othman, and H. Zuhailawati, "Fabrication of high strength $\mathrm{Cu}-\mathrm{NbC}$ composite conductor by high pressure torsion," Materials Science and Engineering A, vol. 528, no. 3, pp. 1750-1756, 2011.

[34] M. T. Marques, V. Livramento, J. B. Correia, A. Almeida, and R. Vilar, "Production of copper-niobium carbide nanocomposite powders via mechanical alloying," Materials Science and Engineering A, vol. 399, no. 1-2, pp. 382-386, 2005.

[35] B. D. Long, H. Zuhailawati, M. Umemoto, Y. Todaka, and R. Othman, "Effect of ethanol on the formation and properties of a $\mathrm{Cu}-\mathrm{NbC}$ composite," Journal of Alloys and Compounds, vol. 503, no. 1, pp. 228-232, 2010.

[36] L. P. Martin, A. M. Hodge, and G. H. Campbell, "Compaction behavior of uniaxially cold-pressed Bi-Ta composites," Scripta Materialia, vol. 57, no. 3, pp. 229-232, 2007.

[37] R. Lapovok, D. Tomus, and C. Bettles, "Shear deformation with imposed hydrostatic pressure for enhanced compaction of powder," Scripta Materialia, vol. 58, no. 10, pp. 898-901, 2008.

[38] S. Scudino, G. Liu, M. Sakaliyska, K. B. Surreddi, and J. Eckert, "Powder metallurgy of Al-based metal matrix composites reinforced with $\beta$-Al3Mg2 intermetallic particles: Analysis and modeling of mechanical properties," Acta Materialia, vol. 57, no. 15, pp. 4529-4538, 2009. 

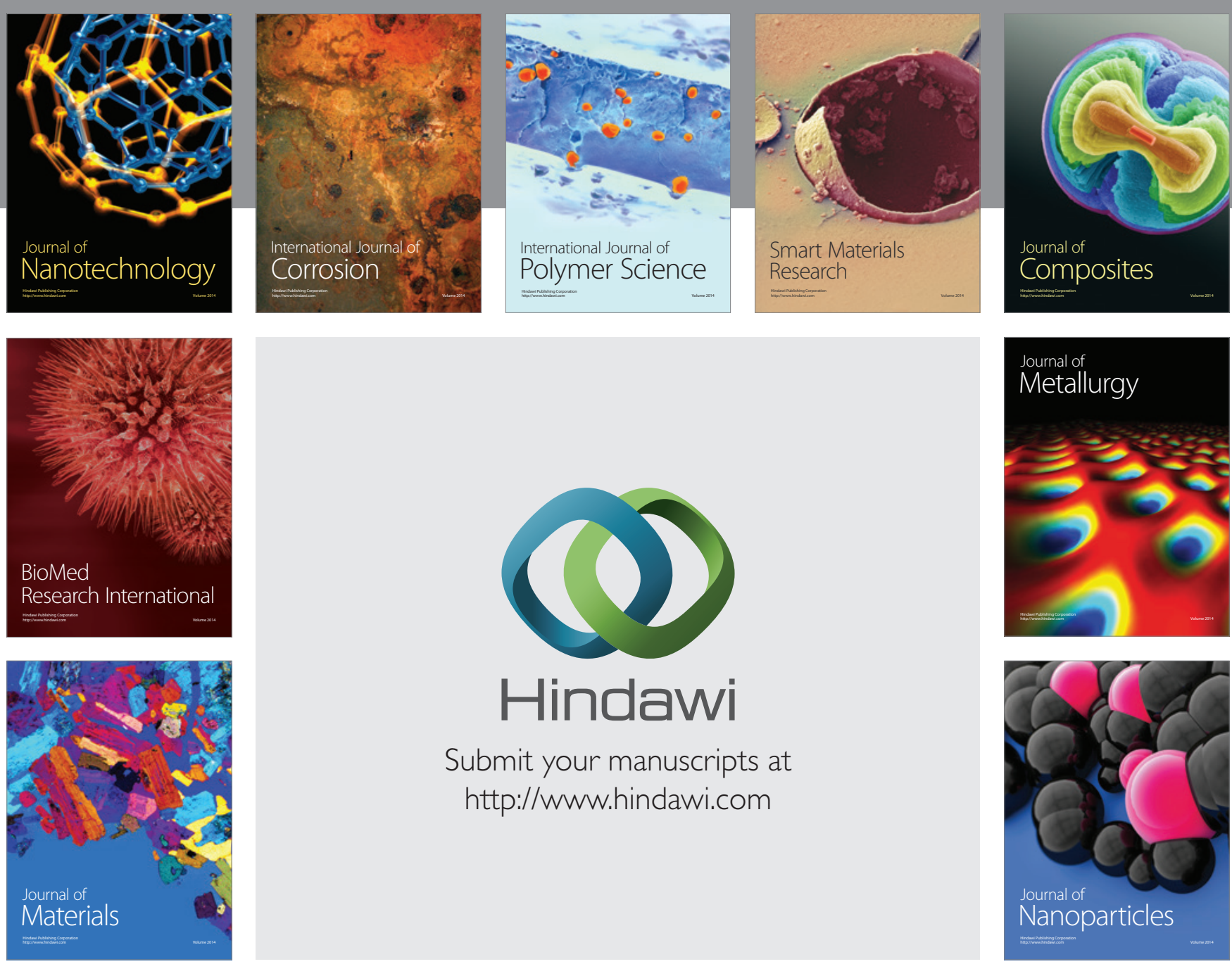

Submit your manuscripts at http://www.hindawi.com
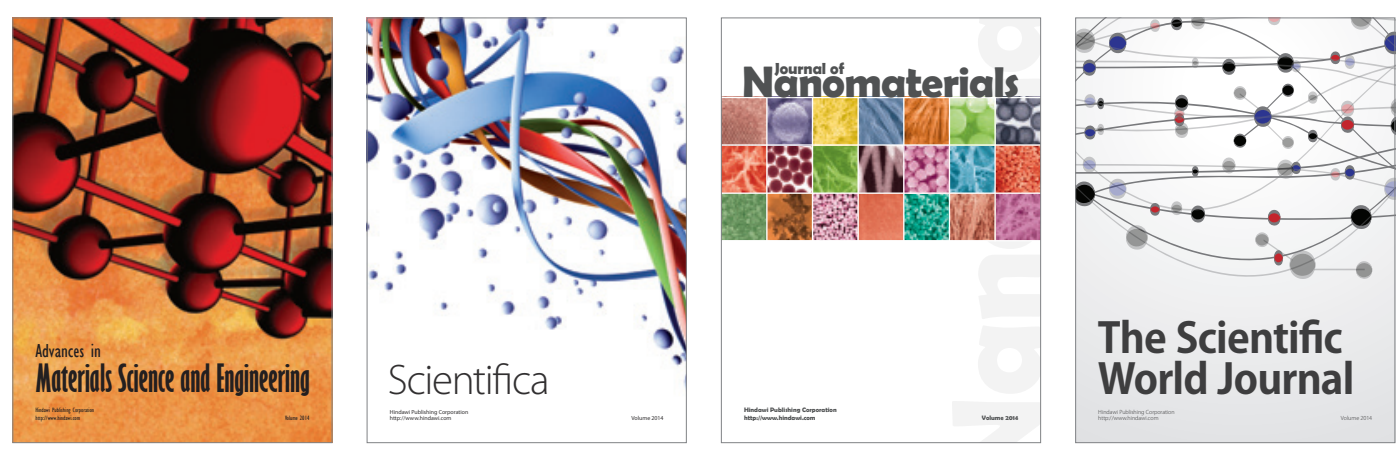

\section{The Scientific World Journal}
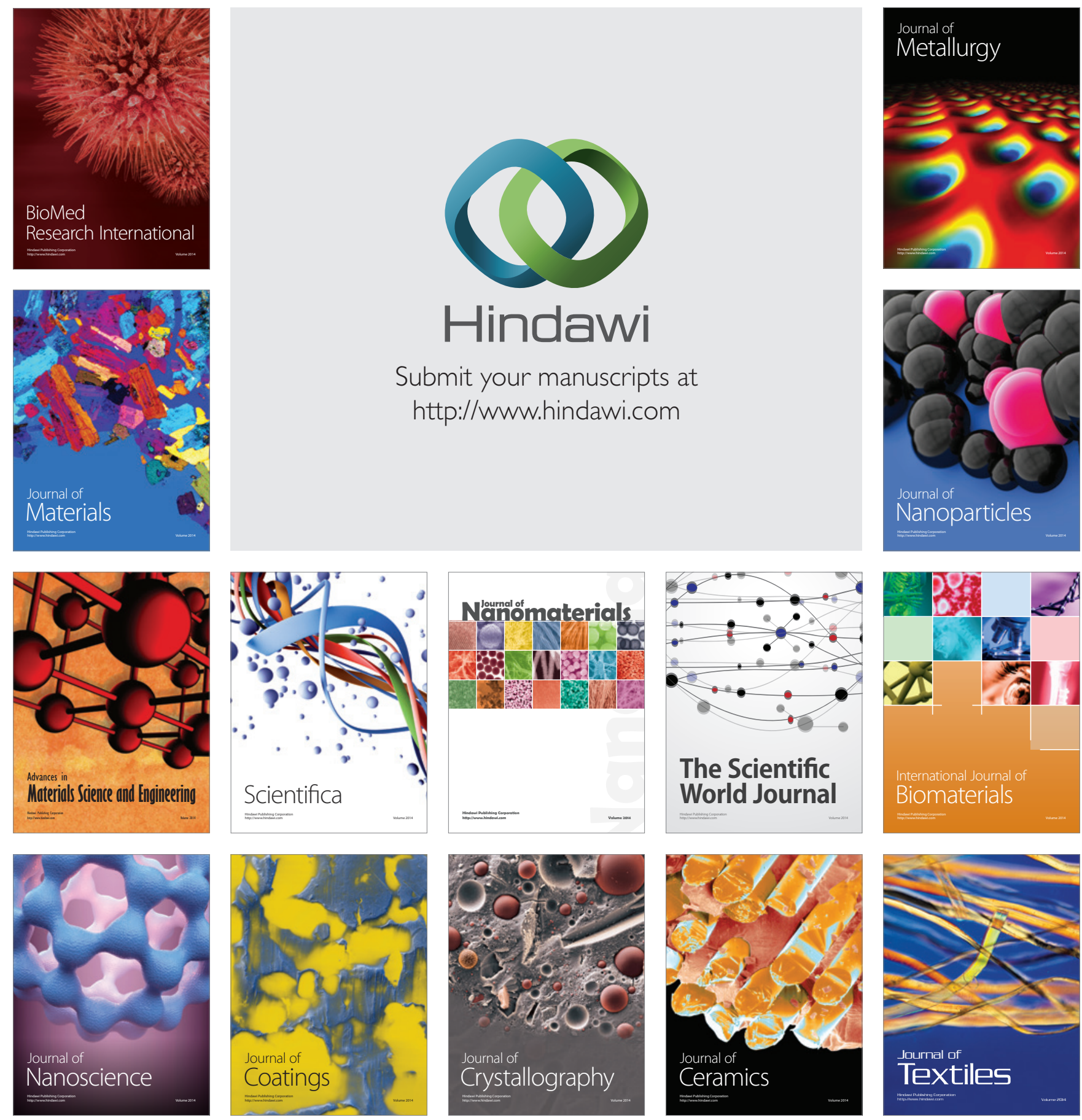